\title{
Perbedaan Kadar Vitamin D antara Hipotiroid Kongenital dan Anak Sehat
}

\author{
Lianda Tamara, Dida A. Gurnida, R.M.Ryadi Fadil \\ Departemen Ilmu Kesehatan Anak Fakultas Kedokteran Universitas Padjadjaran/Rumah Sakit Hasan Sadikin, Bandung
}

Latar belakang. Pertumbuhan dan perkembangan yang optimal pada anak dengan hipotiroid kongenital ditunjang oleh nutrisi yang seimbang dan adekuat. Salah satu mikronutrien yang dibutuhkan adalah vitamin D. Di Indonesia, belum ada data kadar vitamin D pada anak dengan hipotiroid kongenital.

Tujuan. menentukan perbedaan kadar vitamin D antara hipotiroid kongenital dan anak sehat.

Metode. Studi comparative dengan rancangan potong lintang kriteria inklusi anak berusia 1 bulan-5 tahun yang tidak mendapat suplementasi vitamin D. Periode penelitian bulan Juli hingga Desember 2015. Pemeriksaan kadar vitamin D dilakukan dengan metode ELISA. Perbedaan kadar vitamin D pada kedua kelompok dianalisis dengan Mann Whitney.

Hasil. Didapatkan 70 subjek yang memenuhi kriteria inklusi terdiri atas 35 anak dengan hipotiroid kongenital dan 35 anak sehat. Kadar vitamin D rerata pada kelompok hipotiroid kongenital adalah 85,87 nmol/L dan pada kelompok anak sehat adalah 97,74 $\mathrm{nmol} / \mathrm{L}$. Kadar vitamin D pada hipotiroid kongenital berbeda bermakna dengan anak sehat $(\mathrm{p}<0,001)$.

Kesimpulan. Kadar vitamin D pada hipotiroid kongenital lebih rendah daripada anak sehat. Sari Pediatri 2016;18(4):304-7

Kata kunci: anak, defisiensi vitamin D, hipotiroid kongenital

\section{Vitamin D Levels Differences between Congenital Hypothyroidism and Healthy Children}

Lianda Tamara, Dida A. Gurnida, R.M.Ryadi Fadil

Background. Growth and development of children with congenital hypothyroidism are supported by balanced and adequate nutrition. One of the micronutrients needed is vitamin D. In Indonesia, data on vitamin D levels in children with congenital hypothyroidism is still unavailable.

Objective. To determine vitamin D levels differences between congenital hypothyroidism and healthy children.

Methods. This study is a comparative research study with a cross-sectional design. Inclusion criteria for this study were children aged 1 month-5 years who did not receive supplementation of vitamin D. This study was conducted from July to December 2015 . The level of vitamin D performed by ELISA method. Differences in vitamin D levels in both groups were analyzed by Mann Whitney. Results. The subjects were 70 children who met the inclusion criteria, consisted of 35 children with congenital hypothyroidism and 35 healthy children. Mean Vitamin D levels in congenital hypothyroidism was $85.87 \mathrm{nmol} / \mathrm{L}$ and in healthy children was 97.74 $\mathrm{nmol} / \mathrm{L}$. Vitamin D levels in hypothyroid congenital significantly were different with healthy children $(\mathrm{p}<0,001)$.

Conclusion. Serum levels of vitamin D in children with congenital hypothyroidism are lower than in healthy children. Sari Pediatri 2016;18(4):304-7

Keywords: children, congenital hypothyroidism, vitamin D deficiency

Alamat korespondensi: Dr. Lianda Tamara. Departemen Ilmu Kesehatan Anak Fakultas Kedokteran Universitas Padjadjaran/Rumah Sakit Dr. Hasan Sadikin Jl. Pasteur No.38 Bandung 40163. Email: tamaralianda@gmail.com 
K ejadian hipotiroid meningkat pada beberapa dekade terakhir yang memengaruhi kelompok usia yang lebih muda dalam bentuk kongenital di dunia mendekati 1:3.000 angka kelahiran hidup. ${ }^{2}$ Hipotiroid berperan pada terjadinya defisiensi vitamin D sehingga anak dengan hipotiroid kongenital berisiko mengalami defisiensi vitamin $\mathrm{D}$ sehingga dapat memengaruhi pertumbuhan dan perkembangan tulang, masa otot, serta kekebalan tubuh. ${ }^{4}$

Penelitian terdahulu mengenai hubungan hipotiroid dengan vitamin $\mathrm{D}$ pada subjek dewasa dilakukan oleh Bhardwaj dkk ${ }^{1}$ dan Mackawy dkk. ${ }^{4}$ Dilaporkan kadar 25(OH) Vitamin D pada pasien hipotiroid dewasa lebih rendah dibanding dengan kelompok kontrol. Interaksi vitamin D melalui vitamin D receptor (VDR) pada kelenjar tiroid memengaruhi kadar vitamin $\mathrm{D}$ dalam tubuh. ${ }^{1,4}$

Berdasarkan penelitian yang dilakukan oleh Valentina $\mathrm{dkk},{ }^{7}$ 38\% anak Indonesia mengalami defisiensi vitamin D. Faktor yang memengaruhi kadar vitamin $\mathrm{D}$, antara lain, asupan makanan, lokasi geografis, iklim tropis, perbedaan warna kulit, dan perbedaan ras serta paparan terhadap sinar matahari. ${ }^{4}$ Belum terdapat data kadar vitamin D pada anak dengan hipotiroid kongenital di Indonesia sehingga perlu diteliti.

\section{Metode}

Penelitian comparative dengan rancangan potong lintang untuk mengetahui perbedaan kadar vitamin $\mathrm{D}$ antara hipotiroid kongenital dan anak sehat. Subjek penelitian adalah anak yang berobat ke Poliklinik Endokrin Anak Rumah Sakit Dr Hasan Sadikin Bandung pada bulan Juli-Desember 2015. Kriteria inklusi adalah anak berusia 1 bulan sampai dengan 5 tahun dan telah didiagnosis hipotiroid kongenital dengan hasil sidik tiroid. Kriteria eksklusi jika anak menderita penyakit ginjal, hepar, kulit, serta telah mendapat suplementasi vitamin D. Data diperoleh melalui anamnesis, pemeriksaan fisis, pemeriksaan penunjang, dan catatan medis. Pemilihan subjek kelompok kontrol dilakukan secara umur dan jenis kelamin yang setara dan tinggal dalam lingkungan sama dengan subjek hipotiroid.

Pemeriksaan kadar vitamin D dilakukan dengan metode ELISA dengan nilai: defisiensi vitamin D jika serum $25(\mathrm{OH})$ vitamin $\mathrm{D}$ adalah $<50 \mathrm{nmol} / \mathrm{L}$, insufisiensi antara 50-2,5 nmol/L dan kadar normal di atas $75 \mathrm{nmol} / \mathrm{L} .{ }^{8}$ Kedua kelompok diperiksa kadar T3, fT4, dan dengan metode immunoradiometric assay (IRMA). Faktor perancu dalam penelitian ini, antara lain, asupan susu, status gizi, dan hipotiroid kongenital. Analisis dengan uji chi-square dan Eksak Fisher. Semua data yang diperoleh dicatat dan ditabulasi, kemudian dilakukan analisis untuk membandingkan perbedaan rerata vitamin D dilakukan uji Mann-whitney bila data terdistribusi tidak normal. Nilai dari $\mathrm{p} \leq 0,05$ dianggap signifikan secara statistik. Semua penghitungan dengan program SPSS versi 17.

\section{Hasil}

Penelitian dilakukan dengan melibatkan 70 anak yang memenuhi kriteria inklusi terdiri atas 35 subjek hipotiroid kongenital dan 35 subjek kelompok kontrol. Karakteristik umum subjek penelitian tertera pada Tabel 1.

Tabel 1 menunjukkan subjek laki-laki lebih banyak dibandingkan dengan perempuan. Semua subjek penelitian memiliki kadar hormon tiroid normal. Subjek dengan hipotiroid kongenital merupakan pasien rutin berobat di poliklinik endokrin yang rutin mendapat pengobatan hormon tiroid sehingga kadar T3, fT4, dan TSH terkontrol dengan baik.

Faktor yang berhubungan dengan kadar vitamin D yang dinilai, antara lain, asupan susu dan status gizi. Sebagian besar subjek pada kedua kelompok mendapat asupan susu formula yang dikonsumsi setiap hari. Pada kelompok hipotiroid sebagian besar subjek memiliki status gizi baik, demikian pula semua subjek pada kelompok kontrol memiliki status gizi baik. Hubungan asupan susu, status gizi, dan hipotiroid kongenital dengan kadar vitamin D tertera pada Tabel 2.

Tabel 2 menunjukkan tidak terdapat hubungan kadar vitamin $\mathrm{D}$ dengan asupan susu dan status gizi $(p>0,05)$ sehingga tidak diperhitungkan sebagai faktor perancu. Hasil analisis perbedaan kadar vitamin D pada kedua kelompok tertera pada Tabel 3.

Tidak terdapat subjek yang mengalami defiensi vitamin D pada kelompok kontrol. Sepuluh dari 35 anak pada kelompok hipotiroid kongenital mengalami defisiensi vitamin D. Kadar vitamin D pada kelompok hipotiroid kongenital lebih rendah dibanding dengan kelompok anak sehat. 
Lianda Tamara dkk: Perbedaan kadar vitamin D antara hipotiroid kongenital dan anak sehat

Tabel 1. Karakteristik subjek penelitian

\begin{tabular}{lcc}
\hline \multirow{2}{*}{ Karakteristik } & \multicolumn{2}{c}{ Kelompok } \\
\cline { 2 - 3 } Jenis kelamin & Hipotiroid $(\mathrm{n}=35)$ & Kontrol $(\mathrm{n}=35)$ \\
Laki-laki & 21 & 21 \\
Perempuan & 14 & 14 \\
Usia (tahun) & & \\
$\quad$ Rerata (SD) & $2,47(1,77)$ & $2,47(1,77)$ \\
Median & 2,41 & 2,41 \\
T3 (ng/mL) & & \\
Rerata (SD) & $1,89(1,73)$ & $1,39(0,28)$ \\
Median & 1,7 & 1,36 \\
Rentang & $0,80-11,60$ & $0,95-1,87$ \\
fT4 (ng/dL) & & \\
Rerata (SD) & $1,62(1,05)$ & $1,35(0,18)$ \\
Median & 1,4 & 1,36 \\
Rentang & $0,20-6,68$ & $0,98-1,70$ \\
TSHs (ulu/mL) & & \\
Rerata (SD) & $8,01(12,56)$ & $3,22(1,89)$ \\
Median & 2,4 & 2,7 \\
Rentang & $0,1-5,0$ & $2,0-6,6$ \\
\hline
\end{tabular}

Tabel 2. Faktor yang berhubungan dengan kadar vitamin D

\begin{tabular}{lccc}
\hline Faktor risiko & Kelompok hipotiroid & Kelompok kontrol & $\mathrm{p}$ \\
\hline Asupan susu & & 4 & $0,124^{*}$ \\
$\quad$ ASI & 26 & 31 & \\
$\quad$ Formula & & & $0,054^{* *}$ \\
Status gizi & 30 & 35 & \\
$\quad$ Baik & 5 & 0 & \\
$\quad$ Malnutrisi & &
\end{tabular}

Tabel 3. Perbedaan kadar vitamin D (25 Hydroxyvitamin D) antara kelompok hipotiroid kongenital dan kontrol

\begin{tabular}{lccc}
\hline \multirow{2}{*}{ Vitamin D (nmol/L) } & \multicolumn{2}{c}{ Kelompok } & \multirow{2}{*}{$\mathrm{p}^{*}$} \\
\cline { 2 - 3 } & Hipotiroid $(\mathrm{n}=35)$ & Kontrol $(\mathrm{n}=35)$ & \\
\hline Median & 89 & 97,6 & $<0,001$ \\
Rentang & $33,3-101,9$ & $73,2-123,3$ & \\
\hline Keterangan: p: taraf kepercayaan, ${ }^{*}$ : Uji Mann-whitney &
\end{tabular}

\section{Pembahasan}

Kadar vitamin D pada anak hipotiroid kongenital lebih rendah dibanding dengan anak sehat. Penelitian terdahulu oleh Bhardwaj $\mathrm{dkk}^{1}$ dan Mackawy $\mathrm{dkk}^{4}$ dilakukan pada subjek usia dewasa 25-50 tahun dan belum mendapat terapi hormon tiroid sehingga tidak dapat dibandingkan dengan subjek pada penelitian kami yang telah mendapat terapi.

Faktor yang memengaruhi kadar vitamin $\mathrm{D}$, antara lain, genetik, lokasi geografis, iklim tropis, perbedaan warna kulit, perbedaan ras, dan asupan makanan serta paparan terhadap sinar matahari. ${ }^{4,9}$ Faktor genetik yang terjadi adalah polimorfisme gen $V D R$ pada anak dengan hipotiroid kongenital menyebabkan $V D R$ kehilangan afinitas terhadap vitamin $\mathrm{D}$ aktif. Hal tersebut 
mencetuskan defisiensi vitamin D pada hipotiroid kongenital, kecuali apabila asupan makanan dan paparan sinar matahari adekuat karena reseptor tersebut tidak hanya terdapat di tiroid tetapi pada organ lain dengan tidak terdapat polimorfisme pada VDR ${ }^{4,5}$ Dengan kata lain, kadar vitamin D pada anak hipotiroid kongenital dapat normal. Pada kedua kelompok penelitian kami, paparan sinar matahari kemungkinan sama karena tinggal di lingkungan yang sama.

Subjek hipotiroid rutin mendapat pengobatan rata-rata selama 2 tahun sehingga hormon tiroid terkontrol baik, tetapi 10 dari 35 subjek hipotiroid mengalami defisiensi vitamin D. Sepuluh subjek yang mengalami defisiensi vitamin $\mathrm{D}$ kemungkinan disebabkan oleh faktor yang telah disebutkan yaitu asupan makanan. ${ }^{4,5}$ Asupan makanan terbatas pada susu dan tidak memperhitungkan jenis makanan lain, dengan hasil pada kedua kelompok penelitian tidak berbeda bermakna sehingga tidak memengaruhi hasil analisis penelitian ini. Konsumsi suplementasi vitamin D menjadi kriteria eksklusi pada penelitian ini.

Faktor risiko seperti lokasi geografis, iklim tropis, perbedaan warna kulit, dan perbedaan ras pada kedua kelompok penelitian dapat disingkirkan karena kedua kelompok memiliki faktor risiko yang sama. Kedua kelompok memiliki ras Melayu dan bertempat tinggal di Kabupaten Bandung Barat sehingga lokasi geografis dan iklim tempat tinggal relatif sama.

Keterbatasan dalam penelitian kami adalah paparan terhadap sinar matahari tidak dilakukan pengukuran karena belum ada metode baku standar dalam pengukuran jumlah paparan sinar matahari. ${ }^{11}$ Keterbatasan lainnya adalah asupan makanan tidak dilakukan food recall secara rinci sehingga perlu dilakukan penelitian lebih lanjut yang memperhitungan faktor tersebut pada anak dengan hipotiroid kongenital.

\section{Kesimpulan}

Pada penelitian ini didapatkan perbedaan kadar vitamin D antara hipotiroid kongenital dan anak sehat.

\section{Daftar pustaka}

1. Bhardwaj SH, Mishra B, Yadav S, Malik E. Vitamin D levels correlated with hypothyroidism in Indian population: a pilot study. Int J Rec Scie Res 2014;15:984-7.

2. Nair PS, Sobhakumar S, Kailas L. Diagnostic re-evaluation of children with congenital hypothyroidism. Ind Pediatr 2010;47:21-6.

3. Kumorowulan S, Supadmi S. Kretin endemik dan kretin sporadik (hipotiroid kongenital). MGMI 2010;1:3-14.

4. Mackawy AMH, Al-ayed BH, Al-rashidi BM. Vitamin D Deficiency and its association with thyroid disease. Int J Healt Sci 2013;7:14-8.

5. Xavier DA. Vitamin D receptor (VDR) gene polymorphisms and genetic susceptibility to thyroid cancer. Diunduh 19 Mei 2015. Didapat dari: https://ubithesis.ubi.pt/bitstream/ 10400.6/1.pdf.

6. Holick MF. Vitamin D deficiency. N Eng J Med 2007;357: 266-81.

7. Valentina V, Palupi NS, Andarwulan N. Asupan kalsium dan vitamin D pada anak Indonesia usia 2-12 Tahun. J Teknol 2014;25:1-7.

8. Holick MF, Binkley NV, Bischoff-Ferrari HA, Gordon CM, Hanley DA, Heaney RP, dkk. Evaluation, treatment, and prevention of vitamin $\mathrm{D}$ deficiency: an endocrine society clinical practice guideline. [clinical guideline]. J Clin Endocrinol Metab 2011;96:1-20.

9. Misra M, Pacaud D, Petriyk A, Collet-Solberg PF, Kappy M. Vitamin D deficiency in children and its management: review of current knowledge and recommendations. Pediatrics 2008;122:398-417.

10. Lamberg-Allardt C. Vitamin D in food and as supplements programme. Biophysiol Mol Biol 2006;92:33-8.

11. Rey C, Sanchez-Arango D, Lopez-Herce J, Martinez-Camblor P, Garcia-Hernandez I, Prieto B, dkk. Vitamin D deficiency at pediatric intensive care admission. J Pediatr (Rio J) 2014;90:135-42. 